\title{
Knowledge, Attitude and Practice Regarding Tobacco Cessation Methods among the Dental Professionals of Bareilly International University: A Cross-sectional Study
}

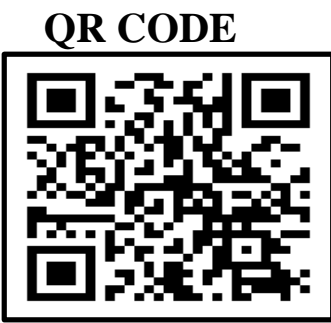

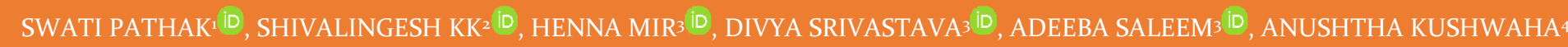

INTRODUCTION: In India, the percentage of deaths caused by tobacco smoking is anticipated to rise from 1.4 percent in 1990 to 13.3 percent by 2020 .Health care experts have done their best to persuade and counsel users to quit the habit through their collaborative efforts.

AIM AND OBJECTIVES: Assessment of dentistry students' attitudes and practices concerning tobacco cessation strategies, as well as the role of information in their promotion.

MATERIALS AND METHODS: This cross-sectional survey was carried out at the Institute of Dental Sciences, Bareilly among the dental professionals, i.e. final year, interns, postgraduates students. The questionnaire was designed to test the knowledge, attitude, and practice of dental students regarding tobacco use. The self-administered survey included a set of questions. Descriptive statistics and Chi-square test had been used to test associations between their responses among age, qualification, and academic year using statistical package for social sciences (SPSS) version 22.

RESULTS: A total of 300 surveys were sent out, with a 96.39 percent response rate. There were 54 percent females and 46 percent males among the 250 participants. Approximately 68 percent of people were between the ages of 20 and 23 . In the current study, 32.4 percent were seeking MDS and 67.6 percent were pursuing BDS. Nearly half of those prefer to prescribe nicotine replacement therapy (NRT) as a cigarette cessation recommendation to patients, followed by self-quitting at $48 \%$ and pharmaceutical approaches at 1.2 percent.

DISCUSSION: More than half of the respondents had an average level of awareness of smoking cessation therapies, and the majority of them had a favorable attitude toward their provision. As a result, it is important to persuade students to develop an interest in learning about tobacco quitting strategies.

KEYWORDS: Oral Cancer, Smoking, Tobacco

\section{INTRODUCTION}

Tobacco usage has risen to the top of the list of preventable illnesses, disabilities, and mortality around the world. Every year, it kills almost 6 million people around the world. Due to the extensive consumption of a range of smoking products and smokeless tobacco forms, India's tobacco concerns are extremely complicated. The majority of the items are made in cottage and small-scale businesses, with different mixes and mass differences in the manufacturing processes. ${ }^{1}$

Tobacco has historically played a crucial role in the attribute of a number of serious oral conditions; it is a risk factor for oral cancer, precancerous conditions, and periodontitis, in addition to being related with a number of cancer and cardiovascular conditions. ${ }^{2}$ Health-care providers are always important in motivating and encouraging their patients to try and quit smoking.

The 2000 Public Health Service clinical guideline presents that "brief physician advice significantly increases long-term smoking abstinence rates." However, according to the above guideline, vigorous interventions are always more effective than less intensive interventions and should be priorly used whenever possible. ${ }^{3}$

The Journal of the Canadian Dental Association has made it a priority to disseminate information about the link between tobacco use and oral illnesses among health institutions and to highlight the responsibility of dental health care practitioners to encourage smoking cessation.

Many western countries, such as the United States, are being held responsible for the quality, safety, and costeffectiveness of their health-care programs and services. ${ }^{6}$ In India, the percentage of tobacco-related deaths is anticipated to increase from 1.4 percent in 1990 to 13.3 percent in 2020.9 Physicians advise is wellreceived and would be followed seriously in practice, according to users.

As a result, doctors should take advantage of the chance to offer smoke cessation therapies during normal clinical visits with patients. ${ }^{10}$ Patients who use tobacco consult dental surgeons the most, thus their

(C) Swati Pathak et al. This is an open access article distributed under the terms of the Creative Commons Attribution License CC-BY-NC 4.o, which permits unrestricted use, distribution and reproduction in any medium, provided the use is not commercial and the original author(s) and source are cited. Submitted on: 26-Aug-2021; Accepted on: 23-Nov-2021 
role in informing patients about the risks and side effects is even more important." Being a motivating counsellor demands a good attitude.

Nicotine replacement therapy has resulted in a significant increase in the rate of cessation with yearlong therapy. In light of the present worldwide tobacco consumption situation, dentists must be informed of tobacco cessation measures such as nicotine replacement therapy (NRT) and counselling schedules. Time and reimbursement concerns, poor education, a lack of further postgraduate training, and a lack of coordination of dental and smoking cessation programs are all reasons for not giving instruction to patients.

The aim of the present study is to assess the dental student's attitude towards tobacco cessation measures in the dental setting and to radiate the influence of knowledge, its effectiveness, gender and curriculum of cessation programmes.

This study provides evidence that dental undergraduates are willing to give smoking cessation counselling to their patients but perceive barriers of knowledge. We, therefore, have attempted to carry out a survey on the knowledge, attitude, and practices of dental health professionals regarding tobacco use.

\section{MATERIAL AND METHODS}

This cross-sectional survey was carried out at institute of dental sciences Bareilly among the undergraduates, i.e., final year, interns and postgraduate students.

A questionnaire was constructed to test the knowledge, attitude, and practice of dental surgeons regarding tobacco use. 18 questions were included in a selfadministered survey instrument: (1) personal information; knowledge of the dangers of smoking and tobacco control policies; (3) smoking cessation interventions delivered to patients; and (4) dental surgeons obtaining training in smoking cessation strategies.

Data were analyzed using SPSS version 22. All clinical and postgraduate students of Institute of Dental Sciences, Bareilly who were present on the day of distribution of the questionnaire, were included in the study.

A Cronbach's alpha value of 0.85 was found after the questionnaire was provided to a sample of 15 students attending a public health dentistry clinical posting who were interviewed to gain input on the questionnaire's overall acceptability, validity, and reliability.

Each person was instructed to complete the questionnaire in front of the investigator with sufficient time to avoid any mistakes. Throughout the procedure, confidentiality was maintained. Data collection and analysis were excluded from incomplete response sheets.

The answer keys for the main questions on nicotine replacement treatment knowledge were created using the tobacco cessation measures guidelines, which were written concurrently with the guidance on smoking cessation strategies produced by the University of York's Centre for Health Economics.

Data analysis: Data from 250 clinical dentistry students were entered into an Excel spreadsheet, and descriptive and inferential statistical analyses were performed. For the analysis, SPSS software version 22 was applied. The chi square test was used. . A critical p value of 0.05 was regarded as significant.

\section{RESULTS}

A total of 300 questionnaires were distributed, out of 260 were returned, out of the 250 participants, $54 \%$ were females and $46 \%$ were males (Figure 1 ). Approximately 68 percent of participants were between the ages of 20 and 23 (Figure 2). According to academic levels, the sample consisted of three groups: fourth-year Bachelor of Dental Surgery (BDS; 28.4 percent), interns (39.2 percent), and postgraduates (32.4 percent). In the current study, 32.4 percent of the students were pursuing a Master of Dental Surgery (MDS) while the majority (67.6\%) were studying a Bachelor of Dental Surgery (BDS).

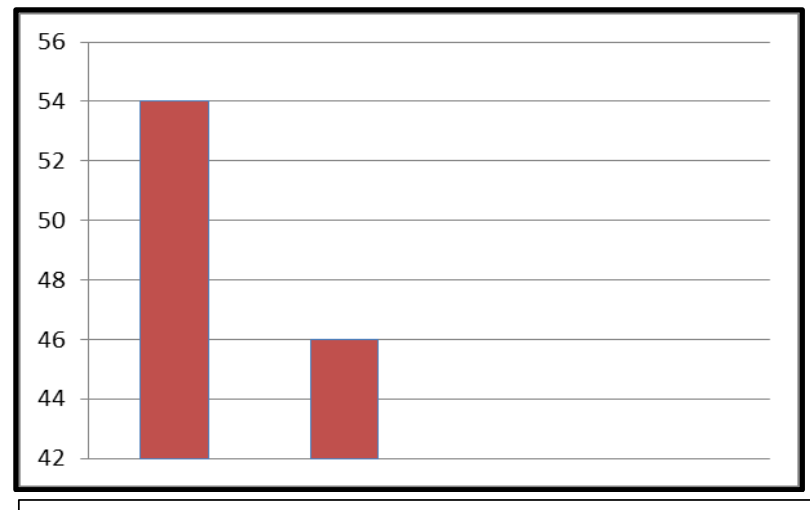

Figure 1. Gender Distribution of the Study Population 


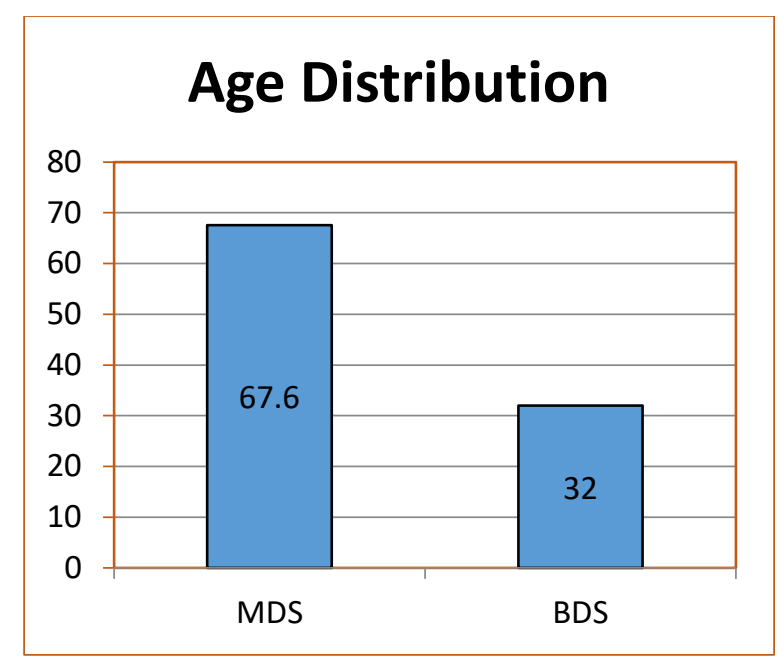

Figure 2. Age Distribution of the Study Population

Knowledge of Treatment Modalities (Table 1)

Only $26 \%$ of students recognized that nicotine nasal spray is absorbed faster, despite the fact that 11.2 percent of respondents were aware of the use of NRTs. Nicotine patches were unknown to $49.6 \%$ of people, while nicotine gums were unknown to $49.2 \%$. Only $42 \%$ were aware that nicotine has an immediate fatal dosage. Only 94 percent of the students were aware of tobacco cessation education programs, but the majority were uninformed of the available pharmacological techniques (nicotex, nasal sprays, nicotine patch, and so on) and their dosage.

\section{Attitudes of Dental Professionals Regarding Tobacco Cessation (Table 1)}

Nearly 53.2 percent of doctors keep track of patients with bad habits, and 79.2 percent feel that nicotine replacement therapy can quadruple the chances of stopping smoking. However, there is reluctance to suggest NRTs for smoking cessation to patients due to a lack of understanding of its applications and negative effects. Almost all (88\%) agreed that stringent legislation should be enacted to prohibit public use of cigarettes, that the media had a significant influence in tobacco promotion, and that the size of warning labels on tobacco products should be increased. A majority of 41.2 percent agreed that prohibiting cigarette use in public places is an effective way of tobacco control. Because physicians are ignorant of these smoking cessation approaches, nearly $97.6 \%$ feel that smoking cessation education should be included in the core curriculum of all health professionals' basic training.
Practice of Dental Surgeons Regarding Tobacco Users Among their Patients (Table 1)

About 97.2 percent of those polled had encountered patients who used cigarettes, and 94.8 percent actively campaigned for tobacco cessation. $46.8 \%$ did not follow-up on their tobacco-using patients or keep a record, and 50 percent preferred to propose NRT as a tobacco-cessation recommendation to their patients, with 48 percent advising self-quitting and 1.2 percent recommending pharmaceutical approaches. As a result, there is a perceived need to be informed of all the ways available to support better treatment for persons contemplating quitting their habit.

\section{DISCUSSION}

For willing patients, dental offices and institutes are regarded a broad setting for advising tobacco cessation intervention services. Dental patients are highly receptive to health messaging, which gives significant encouragement to quit smoking. In the primary care context, there are five major phases to intervention (the "5 As"). Previously, the dentist would "Ask" the patient if he or she uses tobacco, then "Advice" him or her to quit, then "assess" willingness to try to quit, "Assist" the patient, and "arrange" for follow-up contacts to prevent relapse. ${ }^{14}$

According to a study of dental professionals, it is the dentist's obligation to provide tobacco cessation information in order to persuade patients to quit smoking, and the majority were also persuaded to undergo formal training in tobacco cessation methods. In our study it was found that that only half of them question about their clients' tobacco use. According to data obtained globally, up to half of all dental surgeons counsel and offer techniques to quit smoking to their patients. ${ }^{15}$

Similar to Severson et al., only 53.2 percent of respondents in our study kept records or campaigned for smoke cessation strategies among clients, which is consistent with other studies. ${ }^{16}$

Only around 35.6 percent of dental professionals in this research knew about behavioral tobacco cessation approaches, and only about 35.6 percent knew about different types of nicotine replacement treatment. Only 1.2 percent of health professionals were aware of pharmacotherapy, indicating the urgent need to educate health professionals about additional cigarette 


\begin{tabular}{|c|c|c|c|c|}
\hline QUESTIONS & RESPONSE & $\mathbf{N}$ & $\%$ & p VALUE \\
\hline $\begin{array}{l}\text { 1. Do you come across patients } \\
\text { with tobacco habits? }\end{array}$ & $\begin{array}{l}\text { (A) Yes } \\
\text { (B) No }\end{array}$ & $\begin{array}{c}243 \\
7\end{array}$ & $\begin{array}{c}97.2 \\
2.8\end{array}$ & 0.25 \\
\hline $\begin{array}{c}\text { 2. Are you aware of tobacco } \\
\text { cessation education } \\
\text { programme? }\end{array}$ & $\begin{array}{l}\text { (A) Yes } \\
\text { (B) No }\end{array}$ & $\begin{array}{c}235 \\
15\end{array}$ & $\begin{array}{l}94.0 \\
0.6\end{array}$ & 0.589 \\
\hline $\begin{array}{l}\text { 3. Do you provide patient with } \\
\text { tobacco cessation advise? }\end{array}$ & $\begin{array}{l}\text { (A) Yes } \\
\text { (B) No }\end{array}$ & $\begin{array}{c}237 \\
13\end{array}$ & $\begin{array}{c}94.8 \\
5.2\end{array}$ & 0.553 \\
\hline $\begin{array}{l}\text { 4. Which tobacco cessation } \\
\text { method do you prefer to } \\
\text { recommend? }\end{array}$ & $\begin{array}{l}\text { A)Nicotine replacement } \\
\text { therapies } \\
\text { (B) Self quitting method } \\
\text { (C)Pharmacological methods }\end{array}$ & $\begin{array}{c}125 \\
122 \\
3\end{array}$ & $\begin{array}{l}50 \\
48 \\
1.2\end{array}$ & 0.225 \\
\hline $\begin{array}{l}\text { 5. Do you follow up or keep a } \\
\text { record of these patients? }\end{array}$ & $\begin{array}{l}\text { (A) Yes } \\
\text { (B) No }\end{array}$ & $\begin{array}{l}133 \\
117\end{array}$ & $\begin{array}{l}53.2 \\
46.8\end{array}$ & 0.963 \\
\hline $\begin{array}{c}\text { 6. Can nicotine replacement } \\
\text { therapies (NRTs) double the } \\
\text { chance of success in quitting the } \\
\text { habit of smoking? }\end{array}$ & $\begin{array}{l}\text { (A) Yes } \\
\text { (B) No }\end{array}$ & $\begin{array}{c}198 \\
52\end{array}$ & $\begin{array}{l}79.2 \\
20.8\end{array}$ & 0.482 \\
\hline $\begin{array}{l}\text { 7. Do you have adequate } \\
\text { knowledge about NRTs? }\end{array}$ & $\begin{array}{l}\text { (A) Yes } \\
\text { (B) No }\end{array}$ & $\begin{array}{l}89 \\
161\end{array}$ & $\begin{array}{l}35.6 \\
67 \cdot 4\end{array}$ & 0.318 \\
\hline $\begin{array}{l}\text { 8. Nicotine replacement therapy } \\
\text { (NRT) is designed to use for? }\end{array}$ & $\begin{array}{l}\text { (A) } 12 \text { weeks } \\
\text { (B) } 4 \text { weeks } \\
\text { (C) Do not know } \\
\text { (D) } 16 \text { weeks }\end{array}$ & $\begin{array}{r}46 \\
28 \\
135 \\
41\end{array}$ & $\begin{array}{l}18.4 \\
11.2 \\
54.0 \\
16.4\end{array}$ & 0.001 \\
\hline $\begin{array}{l}\text { 9. Which product is absorbed } \\
\text { faster? }\end{array}$ & $\begin{array}{l}\text { (A) Nicotine skin patch } \\
\text { (B) Nicotine gum } \\
\text { (C) Nicotine nasal spray } \\
\text { (D) Do not know }\end{array}$ & $\begin{array}{l}60 \\
41 \\
66 \\
83\end{array}$ & $\begin{array}{l}24.0 \\
16.0 \\
26.0 \\
33.0\end{array}$ & 0.229 \\
\hline $\begin{array}{l}\text { 10. How much dose of nicotine } \\
\text { gum should be advised to a } \\
\text { heavy smoker? }\end{array}$ & $\begin{array}{l}\text { (A) } 4 \mathrm{mg} \\
\text { (B) } 6 \mathrm{mg} \\
\text { (C) } 8 \mathrm{mg} \\
\text { (D) Do not know }\end{array}$ & $\begin{array}{l}28 \\
58 \\
49 \\
123\end{array}$ & $\begin{array}{r}8.0 \\
23.2 \\
19.6 \\
49.2\end{array}$ & 0.006 \\
\hline $\begin{array}{l}\text { 11. Nicotine skin patch should be } \\
\text { worn for? }\end{array}$ & $\begin{array}{l}\text { (A) } 24-48 \text { Hours } \\
\text { (B) } 16-24 \text { Hours } \\
\text { (C) } 8 \text {-10 Hours } \\
\text { (D) Do not know }\end{array}$ & $\begin{array}{l}19 \\
62 \\
45 \\
124\end{array}$ & $\begin{array}{c}7.6 \\
24.8 \\
8.0 \\
49.6\end{array}$ & 0.000 \\
\hline $\begin{array}{l}\text { 12. Nicotine patch and inhaler } \\
\text { are not recommended upto } \\
\text { which age } \\
\text { group? }\end{array}$ & $\begin{array}{l}\text { (A) }<18 \text { Years } \\
\text { (B) }<10 \text { Years } \\
\text { (C) }<15 \text { Years } \\
\text { (D) Do not know }\end{array}$ & $\begin{array}{c}51 \\
54 \\
42 \\
103\end{array}$ & $\begin{array}{l}20.4 \\
21.6 \\
16.8 \\
41.2\end{array}$ & 0.009 \\
\hline $\begin{array}{l}\text { 13. Acute Lethal dose of nicotine } \\
\text { is? }\end{array}$ & $\begin{array}{l}\text { (A) } 20-30 \mathrm{mg} \\
\text { (B) } 40-60 \mathrm{mg} \\
\text { (C) } 80-100 \mathrm{mg} \\
\text { (D) } 30-50 \mathrm{mg}\end{array}$ & $\begin{array}{c}27 \\
105 \\
65 \\
53\end{array}$ & $\begin{array}{l}10.8 \\
42.0 \\
26.0 \\
21.2\end{array}$ & 0.093 \\
\hline $\begin{array}{l}\text { 14. NRTs have the potential to } \\
\text { increase the blood pressure by? }\end{array}$ & $\begin{array}{l}\text { (A) } 0-5 \mathrm{~mm} \mathrm{hg} \\
\text { (B) } 5^{-10} \mathrm{~mm} \text { hg } \\
\text { (C) } 10-15 \mathrm{~mm} \mathrm{hg} \\
\text { (D) Do not know }\end{array}$ & $\begin{array}{r}28 \\
60 \\
52 \\
110\end{array}$ & $\begin{array}{c}11.2 \\
24 \\
20.8 \\
44.0\end{array}$ & 0.000 \\
\hline $\begin{array}{l}\text { 15. Hesitation towards } \\
\text { recommending NRTs for } \\
\text { smoking cessation to } \\
\text { patients is due to }\end{array}$ & $\begin{array}{l}\text { (A)Lack of knowledge about } \\
\text { NRTs } \\
\text { (B) NRTs are not helpful to } \\
\text { quit smoking } \\
\text { (C) NRTs have hazardous } \\
\text { side effects } \\
\text { (D) All of the above }\end{array}$ & $\begin{array}{l}193 \\
20 \\
21 \\
16\end{array}$ & $\begin{array}{l}77.2 \\
8.0 \\
8.4 \\
6.4\end{array}$ & 0.211 \\
\hline
\end{tabular}




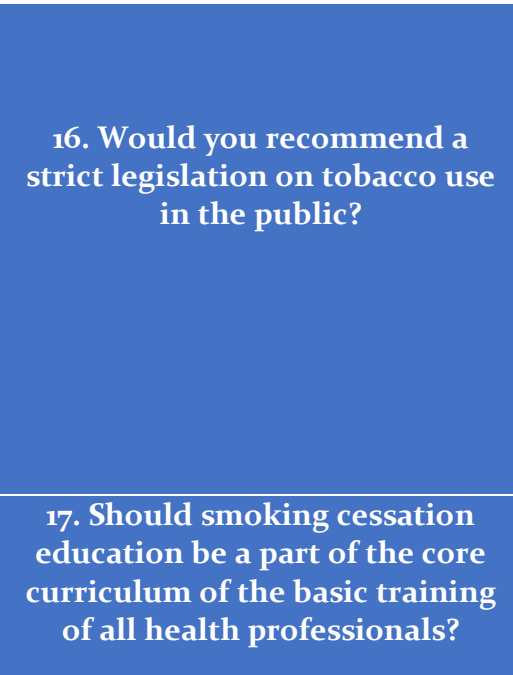

\begin{tabular}{l|} 
(A) Yes \\
(B) No \\
If Yes,
\end{tabular}

\begin{tabular}{c|c|}
\hline 220 & 88.0 \\
30 & 12.0 \\
\hline
\end{tabular}

\begin{tabular}{l|l|} 
If Yes, & \\
(A) If no & 28
\end{tabular}
$103 \quad 41.2$
(B) Ban on public use of tobacco

(C) Increase price of tobacco products

\begin{tabular}{l|l}
4 & 1.6
\end{tabular}

(D) Increase the size of warning labels on the tobacco products

E) All of the above

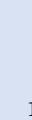

4

111

1.6

$44 \cdot 4$
(A) Yes

(B) No

Table 1. Responses to the questionnaire by the respondents. ( $\mathrm{p} \leq 0.05$ significant, $\mathrm{p} \leq \mathrm{0.01}$ highly significant)

quitting options, comparable to Murthy et al., 2010. ${ }^{17}$

In contrast to Omolara et al., over 16 percent of them believe that nicotine replacement therapy is ineffective in helping people stop smoking, and 6.40 percent believe that nicotine gums have negative side effects. Many students believe that cessation therapy sessions are ineffective in getting patients to quit smoking. Furthermore, more than $80 \%$ of respondents said their time could be better spent on other activities. Approximately 94.8 percent of responders encourage patients to engage in cigarette cessation measures comparable to those recommended by Omolara et al. According to the findings of this study, many of the dental students who took part in the survey had no prior experience in treatment techniques for nicotine replacement therapy. Furthermore, there is no demand for these services because of patient expectations. If smoking cessation behavior in dental practice is to be improved, training in the dental curriculum must be included, and over 250 (97.2 percent) respondents agreed that cessation training is an important aspect of the dental curriculum, comparable to the findings of the Karbhari et al. study. The insufficiency of training, according to Ehizele et al., is a barrier to promoting cessation services among dental students. The inclusion of smoking cessation in dental colleges' curricula, as well as the availability of continuing dental education in tobacco intervention, are critical for dental professionals to have up-to-date information and to equip them to play an effective role in overall smoking cessation and prevention. As a result, it is necessary to provide such training to health-care workers. The dentist's didactic and practical training takes place in the framework of the practice's day-today operations.

\section{CONCLUSION}

Our research recommended that a tobacco documentation centre be established within the institutes, with suitable training provisions for smoking cessation approaches. The requirement for introducing advice and training services for health care workers in tobacco-cessation counselling strategies has been recommended by researchers. It was also stated that experts' positive attitudes regarding smoking cessation do not always transform into good practice. This could be due to roadblocks encountered in putting available knowledge into practice and translating a positive attitude into clinical practice. Further research involving a variety of institutes will provide additional light on the organizational practice of smoke cessation treatments in India. To spread the vision of tobaccofree zones across the country, it is important that smoking cessation counselling is entrenched in the dental curriculum as future role models.

\section{REFERENCES}

1. Reddy KS, Gupta PC. Report on Tobacco Control in India. New Delhi, India: Ministry of Health and Family Welfare; 2004 [Last Accessed on $7^{\text {th }}$ July, 2021].

2. Preber $\mathrm{H}$, Bergstrom J. Effect of smoking on periodontal healing following surgical therapy. J Clin Periodontol. 1990;17:324-8.

3. Albert D, Ward A, Ahluwalia K, et al. Addressing tobacco in managed care: a survey of dentists' 
knowledge, attitudes, and behaviors. American Journal of Public Health. 2002;92(6):997-1001.

4. Mirbod SM, Ahing SI. Tobacco-associated lesions of the oral cavity: Part II. Malignant lesions. J Can Dent Assoc. 2000; 66(6):308-11.

5. Lavelle C, Birek C, Scott DA. Are nicotine replacement strategies to facilitate smoking cessation safe? Journal-Canadian Dental Association 2003;69(9):592-7.

6. Chassin MR, Galvin RW. The urgent need to improve health care quality. Institute of Medicine National Roundtable on Health Care Quality. JAMA 1998;280:1000-5.

7. John S, Davis M. Quality improvement and accountability in the treatment of tobacco dependence: the need for a national training and certification programme, Tobacco Control 2000;9:355-8.

8. Saddichha S, Rekha DP, Patil BK, et al. Knowledge, attitude and practices of Indian dental surgeons towards tobacco control: advances towards prevention. Asian Pacific Journal of Cancer Prevention 2010;11(4):939-42.

9. Reddy KS, Gupta PC. Tobacco control in India. New Delhi: Ministry of Health and Family Welfare, Government of India 2004:43-7.

10. Tessier JF, Thomas D, Nejjari C, et al. Attitudes and opinions of French cardiologists towards smoking. European journal of epidemiology 1995;11(6):615-20.
11.Vanobbergen J, Nuytens P, Van Herk M, et al. Dental students' attitude towards anti-smoking programmes: a study in Flanders, Belgium. European Journal of Dental Education 2007;11(3):177-83.

12. Raw M, McNeill A, West R. Smoking cessation guidelines for health professionals. A guide to effective smoking cessation interventions for the health care system. Health Education Authority. Thorax. 1998;53 Suppl 5 Pt $\quad$ 1(Suppl5):S1-S19. https://doi.org/10.1136/thx.53.2008.s1

13. Salman K, Azharuddin M, Ganesh R. Attitude of Dental Students Towards Tobacco Cessation Counselling in Various Dental Colleges in Tamil Nadu, India. Int J Sci Stud. 2014;2(4):20-4.

14. Warnakulasuriya KA, Johnson NW. Dentists and oral cancer prevention in the UK: opinions, attitudes and practices to screening for mucosal lesions and to counselling patients on tobacco and alcohol use: baseline data from 1991. Oral diseases 1999;5(1):10-4. 15. Severson HH, Eakin EG, Stevens VJ, et al. Dental office practices for tobacco users: independent practice and HMO clinics. American Journal of Public Health 1990;80(12):1503-5.

16. Murthy P, Saddichha S. Tobacco cessation services in India: recent developments and the need for expansion. Indian Journal of Cancer 2010;47(5):69-74.

Cite this article as:

Pathak S, Shivalingesh KK, Mir H, Srivastava D, Saleem A, Kushwaha A. Knowledge, Attitude and Practice Regarding Tobacco Cessation Methods among the Dental Professionals of Bareilly International University: A Cross-sectional Study. Int Healthc Res J. 2021;5(8)OR1-OR6. https://doi.org/10.26440/IHRJ/0508.11469

AUTHOR AFFILIATIONS: (*Corresponding Author)

1. $3^{\text {rd }}$ Year Postgraduate Student, Department of Public Health Dentistry, Institute of Dental Sciences, Bareilly

(https://orcid.org/oooo-0oo2-4353-119X),

2. Professor \& Head, Department of Public Health Dentistry, Institute of Dental Sciences, Bareilly

(https://orcid.org/oooo-0002-4636-522X)

3. MDS, Public Health Dentistry (https://orcid.org/oooo-0oo2-3233-2654, Dr. Henna Mir), (https://orcid.org/oooo-0oo2-1755-8436, Dr. Divya Srivastava), (https://orcid.org/oooo-0oo1-6900-0613, Dr. Adeeba Saleem)]

4. $2^{\text {nd }}$ Year Postgraduate Student, Department of Public Health Dentistry, Institute of Dental Sciences, Bareilly

Source of support: Nil, Conflict of interest: None declared

Contact Corresponding Author At: swati.anatomy[at]gmail[dot]com 